\title{
ГЕНЕЗА РОЗВИТКУ ДЕРЖАВНО-ПРИВАТНОГО ПАРТНЕРСТВА
}

\author{
МАСЛОВ Владислав Олександрович \\ аспірант Університету банківської справи \\ ORCID ID: https://orcid.org/0000-0002-8793-6033 \\ e-mail:maslov.v@ubs.edu.ua
}

\begin{abstract}
Анотація. Розглянуто етапи та кониептуальні основи виникнення та формулювання парадигми державно-приватного партнерства. Виокремлено основні характерні ознаки співпрачі держави та приватного бізнесу у вченнях представників економічних шкіл впродовж усього періоду формування економічної науки. При написанні статті використано історичний та логічний методи, методи наукової абстракиії та порівняння.

Ключові слова: державно-приватне партнерство, економічна теорія, меркантилізм, фізіократизм, кейнсіанство, неокласицизм.
\end{abstract}

Постановка проблеми. Актуалізація співпраці між державою та приватним бізнесом на сьогодні залишається одним із основних інструментів реалізації державою своїх функцій 3 метою зростання конкурентоспроможності національної економіки. Відсутність основоположних знань про генезис формування державно-приватного партнерства зумовлюе наявність проблемних моментів у його цілісному впровадженні, що безумовно відображається на виборі напряму та глибини дослідження.

Аналіз досліджень та публікацій. Основні моменти формування та
Аннотация. Рассмотрень этапь и кониептуальные основы возникновения и формулирования парадигмы государственночастного партнерства. Вылделены основные характерные признаки сотрудничества государства и частного бизнеса в учениях представителей экономических школ на протяжении всего периода формирования экономической науки. При написании статьи использованы исторический и логический методы, методы научной абстракиии и сравнения.

Ключевые слова: государственночастное партнерство, экономическая теория, меркантилизм, физиократизм, кейнсианство, неоклассицизм.

виокремлення державно-приватного партнерства як однієї із основ реалізації державою своїх функцій розглядалися у працях Г. Атаманчука, О. Василенко, В. Вишнякова, Н. Ларіної, В. Місюри, С. Майстро, О. Петроє, О. Радченка, Н. Сорокіної, Ю. Тихомирова, Н. Чепурнової та інші. Зазначені автори акцентують увагу на необхідності зміни державноадміністративного стилю управління на партнерський, запроваджений на механізмі державно-приватного партнерства, який забезпечить «співро-бітництво між органами державної влади, органами місцевого самоврядування, приватним сектором 
та інститутами громадянського суспільства». Не у повній мірі залишаються дослідже-ними основні концептуальні принципи формування державно-приватного партнерства в впродовж усього історичного шляху формування економічної науки.

Мета статті. Метою статті $\epsilon$ послідовний аналіз теоретичних та методичних положень категорії державно-приватного партнерства у більшості економічних шкіл, міжнародних організацій та формулювання авторської дефініції досліджуваного поняття.

Виклад матеріалів дослідження. Аналізуючи генезу розвитку поняття ДПП крізь призму розвитку економічної науки i формування економічних теорій варто зауважити, що попри різноманітність підходів представників різних наукових шкіл, які часто були діаметрально протилежними, всі вони розглядали проблему рівня впливу державного регулювання на приватний сектор економіки $з$ позиції антагонізму.

Основи теорії державно-приватного партнерства були закладені у вченнях меркантилістів і пов'язуються 3 початком формування $\mathrm{i}$ розвитку зовнішньоекономічних зв'язків та наданням при цьому державою допомоги ринку i приватним підприємцям. Меркан-тилізм як економічна школа i, водночас, напрям господарської політики, підтримував ідею держав-ного протекціонізму на внутрішньому й зовнішньому ринках, активного впливу держави на діяльність приват-ного капіталу шляхом придбання промислових секретів, машин і устаткування, фінансування розвитку інфраструктури. Прихильники цього напряму Т. Мен, Ж.-Б. Кольбер і А. Монкретьєн обгрунтовували необхідність збільшення багатства не стільки в окремих людей, скільки в державі загалом [1].

Представники іншої наукової школи - фізіократизму, А. Тюрго, Ф. Кене, теоретично обгрунтовували необхідність і практику впливу держави на економічні процеси, і відстоювали ліберальну концепцію зв'язків держави i приватного капіталу, яку поглибили i розвинули засновники лібералізму Дж. Локк, а згодом А. Сміт [2].

Основоположний принцип економічного лібералізму - заохочення конкуренції i застосування державного регулювання тільки там, де вона, неможлива, став підгрунтям поняття «раціональної поведінки» «homo economicus» - людини економічної. Лібералісти розвивали ідею «чесного партнерства» як найважливішої економічної функції держави, потрібної для налагодження роботи ринкового механізму, і наголошували на необхідності відстоювання державою дотримання гарантій функціонування приватного капіталу. А. Сміт у праці «Дослідження про природу і причини багатства народів» вперше комплексно обгрунтував економічний і політичний лібералізм, наполягаючи, що «вільне поєднання й конкурентна боротьба приватних інтересів принесуть велику користь суспільству і матимуть кращі результати, аніж втручання держави, яка повинна лише забезпечувати умови для конкуренції. I в такому обмеженні іiі функції полягає інтерес підприємців» [2].

Прихильник господарського лібералізму Дж.-С. Мілль, аналізуючи 
взаємодію приватного капіталу й держави, виступав за широкий розподіл приватної власності серед громадян при безумовному дотриманні їх економічних прав, i обстоював верховенство громадян над урядом. Мілль вважав, що самостійне ділове життя $\epsilon$ важливою складовою практичного виховання народу, а уряд повинен визначити приватному підприємництву умови діяльності, які забезпечують загальну вигоду. Ведення справ, на думку вченого, «краще надати приватному капіталу 3 активними агентами, а контроль належного виконання прийнятих ним на себе обов'язків - суспільству» [3].

Німецький учений $Ф$. Ліст, який заклав основи історичної школи політичної економії, обгрунтовував необхідність державного втручання у ті сфери економіки, які недостатньо прибуткові для приватного капіталу i довго окупаються, наприклад, інфраструктура [3].

Дж.-М. Кейнс i кейнсіанство в контексті розвитку ДПП збагатили теорію економічної думки обгрунтуванням системи державного добробуту та підвищення соціальної захищеності громадян внаслідок посилення втручання держави в економіку i iî ефективній співпраці 3 приватним капіталом за межами сфери інфраструктури. «Тенденція до розширення й поглиблення співпраці держави 3 приватним капіталом впродовж XX століття стала визначальною i у виробничій сфері. Якщо класичне кейнсіанство розглядало переважно непрямі методи державного регулювання економіки за допомогою бюджетних i грошовокредитних важелів,

TO неокейнсіанство досліджувало теорію економічного зростання i циклів, приділяючи, одночасно, увагу взаємодії приватного капіталу 3 державою у формі участі останнього в розвитку інфраструктури. Від iï стану залежить i динаміка суміжних промислових галузей, рівень інвестицій у них» [4].

А. Маршалл, засновник неокласичного напряму економічної теорії, який прийшов на зміну кейнсіанству, конкуренцію розглядав як опору для розвитку свободи підприємництва, визнаючи можливість державного втручання для забезпечення повноцінного функціонування економіки. Він вважав, що в ринковій економіці уряд повинен обгрунтувати застосування тих або інших заходів впливу для гарантування вигоди крупним державним підприємствам, без яких унеможливлюється їх ефективне функціонування[3]. Отже, А. Маршалл надавав перевагу ринковому механізму, при звуженні прямої участі держави в підприємництві.

В останній третині XIX ст. бурхливий розвиток НТР дав поштовх розвитку неолібералізму, представниками якого були німецький вчений В. Ойкен i Ф. фон Хайєк [5], які розглядали поєднання державної участі в господарській і соціальній сферах у формі розробки спільних програм між урядом i крупними підприємствами, співпраці приватного капіталу й держави, із залученням фінансових ресурсів останнього i банківського сектора. Неолібералізм культивував розширену взаємодію держави 3 приватним капіталом, поєднання конкуренції 3 державним регулюванням, особливо в неприбуткових секторах (освіта i наука, соціальне забезпечення, 
охорона здоров'я) [6].

Упродовж XX ст. господарський вплив держави почав суттєво зростати, в результаті чого з'явився альянс держави 3 приватною ініціативою у формі «змішаної економіки» Це стало приводом до розвитку неокейнсіанства, представником якого $є$ П. Самуельсон, якому вдалося поєднати елементи неокейнсіанського і неокласичного напрямів економічної теорії і сформувати концепцію змішаної економіки [6]. Вчений розглядав можливість мінімального втручання держави в господарські процеси за таких умов:

при рівності доступу до людських і природних ресурсів;

- при однаково сприятливих можливостях економічних суб'єктів;

- при відсутності заздрості й інших суб'єктивних чинників.

У таких умовах, вважав Самуельсон, «необхідність виконувати державі хоч якісь функції взагалі б відпала, іiі роль звелася б до нуля, а 3 нею - i необхідність у змішаній економіці» [7].

Пізніше, разом 3 іншим американським економістом Р. Макгрейвом, П. Самуельсон розробив основні положення абстрактної теорії суспільних благ, в якій показано, що державні й приватні економічні інтереси не завжди знаходяться в конфлікті i що можна визначити напрями і раціональні межі державної участі в господарських процесах, доцільність і ступінь іiі взаємодії 3 приватним капіталом.

$\mathrm{У}$ середині $\mathrm{XX}$ століття на макрорівні змішана економіка стала поєднанням регулюючого і ринкового механізмів. На рівні мікроекономіки це виявилося в розподілі праці і кооперації виробництва за участю крупних, середніх i дрібних підприємств. Державі, з одного боку відводилася роль законодавця макроекономічної політики, особливо в періоди труднощів, а 3 іншого самостійного господарського гравця зі своєю програмою дій.

Після масштабної світової приватизації 1980-1990-х років частка держави в капіталі підприємств скоротилася. Відбувалося взаємопроникнення складових змішаної економіки 3 чергуванням фаз націоналізації і приватизації [8]. Фактично лише в другій половині XX ст. 3'явилися перші наукові концепції саме співпраці держави і бізнесу, які вилилися у ДПП, в рамках якого держава передавала частину своїх функцій бізнесу, запозичуючи у нього певні правила роботи.

Сьогодні ДПП все частіше $\epsilon$ комплексом договірних взаємовідносин між внутрішніми і зовнішніми інвесторами. Серед форматів ДПП контракти, угоди, особливі економічні зони, спільні підприємства, концесії, які ми будемо детальніше розглядати у наступних параграфах роботи.

Економісти-науковці розглядають термін «державно-приватне партнерство» в широкому та вузькому розумінні. У широкому розумінні ДПП - це «система відносин держави та бізнесу, яка широко використовується як інструмент національного, міжнародного, регіона-льного, міського, муніципального, економічного i соціального розвитку» [8], «взаємовигідне середньо- і довгострокове співробітництво між державою і бізнесом, що реалізується в різних формах (починаючи від контрактів на виконання робіт, 
акціонування

i

закінчуючи

консультаціями держави i бізнес асоціацій) i яке ставить за мету вирішення політичних i суспільно значимих завдань на національному, регіональному і місцевому рівнях» [9], «довгострокове співробітництво, що регулюється договором, між державою i приватним сектором 3 метою виконання суспільних завдань, яке охоплює весь життєвий цикл відповідного проекту: від планування до їх експлуатації, включаючи технічне обслуговування» [8, с.4]. У вузькому - ДПП $є$ механізмом економічної політики держави, який дозволяє залучити позабюджетні джерела фінансування, а також інтелектуальні, технологічні, управлінські й інші ресурси приватного сектора до вирішення суспільноважливих інвестиційних завдань.

Предметною областю науковцівполітологів є ідеологічні засади ДПП, його роль і місце в політичній системі суспільства та політичних відносинах. Так, у працях Ф. Узунова зазначено, що в державі ще "не сформована активна ідеологія державноприватного партнерства, яка пропонує мирне співіснування різних соціальних груп зі специфічними i часто протилежними інтересами, цивілізовані форми подолання суперечностей i досягнення консенсусу, що виявляється у поширенні правового нігілізму, відсутності ціннісно-нормативного консенсусу, недостатньому розвитку людського і соціального капіталу". Таку ж думку, але в різних інтерпретаціях висловлюють у наукових дослідженнях вчені А. Близнюк, В. Боделан, В. Бульба, О. Толстенко, Р. Чапін, А. Шуліка.
Щодо представників економічної науки, то, як зазначає Д. Лаврентій, вони «виносять у фокус дослідницької уваги фінансово-економічні аспекти застосування механізмів ДПП» . Зокрема, Г. Ходж і К. Грейв під ДПП описують фінансові моделі, які дозволяють державному сектору залучати й використовувати капітал приватного сектора для поліпшення можливостей діяльності як регіонального уряду, так i приватних компаній, залучених у проект. Таким чином, автори підкреслюють наявність тісних фінансових взаємозв'язків між державою i приватним сектором, які утворюються при реалізації спільного проекту при використанні механізму ДПП. Близьке до вказаного визначення дають Д. Грімсі і М. Левіс. Під ДПП вони розуміють відносини, в рамках яких відбувається розподіл ризиків і які грунтуються на спільній для держави та одного або декількох приватних партнерів меті надання погодженого державою результату i державної послуги. Н. Мартинова розглядає систему соціального партнерства, насамперед, як «ринкове явище, що почало складатися завдяки радикальним перетворенням в економіці» [9].

На сьогодні міжнародні урядові й фінансові інститути дають такі визначення ДПП:

- «всі види взаємодії між державним і приватним сектором по формуванню стандартів, наданню послуг і доступу до інфраструктури» [10];

- «базується на контрактних взаємовідносинах між державними структурами й представниками приватного сектора, спрямованих на збільшення ступеня участі приватного 
бізнесу в реалізації транспортних проектів» [11];

- «це інституційний і організаційний альянс між державою і бізнесом, створений 3 метою реалізації суспільно значимих проектів і програм у широкому спектрі галузей від промисловості і НДДКР до сфери послуг» [12. с.18-19];

- «середньострокові й довгострокові відносини між державним і приватним сектором; партнерство містить у собі розподіл ризиків і доходів, а також використання кваліфікації і ресурсів державного і приватного сектора для досягнення намічених стратегічних результатів в інтересах держави» [13];

- «сукупність спеціальних правил і технологій для вирішення проблем соціально-економічного розвитку» [14].

Як бачимо, усі визначення є досить загальними і не розкривають цілей, завдань, принципів i галузевих особливостей кожної зі сторін партнерських відносин. Здебільшого, вони є розпливчастими і зводяться до конкретизації відносин партнерів на мікроекономічному рівні.

Держава в проектах ДПП є одночасно законотворцем, контролером і бізнес-партнером, який бажає одержати різні преференції від співпраці з приватним бізнесом, і який має в своєму розпорядженні речові, неречові, виробничі, фінансові та інші ресурси. Держава не має достатньо коштів для модернізації, обслуговування й розширення інфраструктури, яка знаходиться в її власності та $є$ менш ефективним власником, ніж приватний бізнес [15].

Приватний сектор має в своєму розпорядженні ресурси, які відсутні у держави, володіє інструментами більш раціонального їх використання i за- цікавлений в одержанні прибутку та конкурентних переваг за рахунок освоєння таких економічних ніш, які до того або не були представлені на ринку або знаходилися у винятковому володінні держави. Отже, одне з важливих завдань у рамках ДПП - таке узгодження інтересів учасників, яке дозволило б кожному 3 них реалізувати власні потреби 3 мінімальними втратами і одержати вигоди.

Таким чином, $з$ урахуванням проведеного аналізу теоретикометодологічних підходів до визначення ДПП, вважаємо за необхідне уточнити сутність та економічний зміст цієї дефініції з точки зору системного підходу, врахування економічних передумов виникнення самого ДПП як явища, можливостей фінансування проєктів і розподілу ризиків ДПП.

Державно-приватне партнерство це організаційно, економічно та юридично оформлена система відносин взаємовигідної співпраці державного і приватного секторів економіки, заснована на ефективному розподілі ризиків, яка одночасно зорієнтована на одержання максимального ефекту від реалізації проектів та задоволення інтересів усіх суб'єктів в умовах обмеженості ресурсів кожної окремої сторони таких відносин.

На відміну від існуючих визначень, уточнена інтерпретація поняття ДПП дозволяє без обмежень розглядати різні організаційні форми і методи фінансування проєктів і розподілу відповідальності за ризики при передаванні частини публічної квідповідальності за процес забезпечення соціально-економічного розвитку зі сфери компетенції держави у приватний сектор. 
Висновки. Створення парадигми будь-якого явища, процесу чи категорії визначається вивченням теоретичного підгрунтя його становлення, особливо важливим $є$ вивчення трактування сутності та ознак досліджуваної категорії основними економічними школами.

Дослідження історичного та логічного аспектів формування теоретикометодичних положень категорії «державно-приватне партнерство» дало можливість виокремити суспільну та індустріальну корисність налагодження зв'язків між державним та приватним бізнес-сектором, визначити особ- ливості глобального та локального економічного трактування поняття, проаналізувати особливості визначення досліджуваної категорії міжнародними інституціями.

Зазначений аналіз теоретичних аспектів категорії «державно-приватне партнерство» із виявленими особливостями та характеристиками сутності цього поняття дозволив сформулювати авторську дефініцію, яка у повній мірі може використовуватися у подальших дослідженнях напрямів розвитку державно-приватного партнерства в Україні.

\section{Список використаної літератури}

1. Юрах В. Меркантилізм в історіографії розвитку теорій інвестицій та інвестиційної діяльності. Наукові записки. 2010. Вип. 13. С. 319.

2. Смит А. Исследование о природе и причинах богатства народов. М.: Эксмо, 2007. $960 \mathrm{c}$.

3. Хрестоматия по экономической теории. [сост. Е. Ф. Борисов]. М. : Юристъ, 2000. $536 \mathrm{c}$.

4. Коддингтон А. Кейнсианская экономическая теория: в поисках главных принципов. Истоки. 1998. Вып. 3. С. 338.

5. Єфименко Т. І. Державно-приватне партнерство в системі регулювання економіки: монографія. К. : [б. в.], 2012. 371 с.

6. Маршалл А. Основы экономической науки [предисл. Дж.М.Кейнс; пер. с англ. В.И.Бомкина, В.Т.Рысина, Р.И.Столпера]. М.: Эксмо, 2007. 832 с.

7. Самуэльсон П., Нордхаус В. Экономикс: Реферат учебника. Экономические науки. 1990. № 7. С. 114-128.

8. Павлюк К. В., Павлюк С. М. Сутність і роль державно-приватного партнерства в соціально-економічному розвитку держави. Наукові праці КНТУ. Економічні науки. 2010. № 17. С. 10-19.

9. Кузьминов Я. И. Государственно-частное партнерство: на пути к эффективности. URL: http://www.hse.ru/lingua/en/news/recent/4016069.html (дата звернення: 24.04.2021) 
10. Public private partnerships. HM Treasury. 2008. URL : http://www.hmtreasury.gov.uk/documents/public_private_partnerships/ppp_index.cfm. (дата звернення: 24.04.2021)

11. Public-Private Partnership: PPPs Defined. United States Department of Transportation, Federal Highway Administration. 2008. URL : http://www.fhwa.dot.gov/ppp/defined.htm. (дата звернення: 24.04.2021)

12. Риски бизнеса в частно-государственном партнерстве. Национальный доклад. М. : Ассоциация менеджеров, 2007. 116 с.

13. Использование концессии как формы государственно-частного партнерства для реализации крупных предпринимательских проектов в автодорожной отрасли РФ. М. : МИРБИС, 2007. 25 c.

14. Гриценко А.А. Совместно разделённые отношения: труд, собственность и власть. Экономика Украины. 2003. № 6. С. 50-58.

15. Брайловський I. А. Контракт постачання та управління як модель державноприватного партнерства. Вісник Донецького нащіонального університету. Серія «Економіка і право». 2013. № 1. С. 24-26. 